\title{
The Fixation of Tetanus Toxin, Strychnine, Serotonin and other Substances by Ganglioside
}

\author{
By W. E. vaN HEYNINGEN \\ Sir William Dunn School of Pathology, University of Oxford
}

(Received 26 September 1962)

\begin{abstract}
SUMMARY
Although tetanus toxin is fixed by brain ganglioside, it is not fixed by a number of substances more or less closely related to brain ganglioside, or by naturally occurring brain ganglioside not containing hexosamine, or by a hexosamine-containing ganglioside from Tay-Sachs brain. Isolated brain gangliosides may vary considerably in their toxin-fixing capacities. In chloroform + methanol extracts of brain a number of gangliosides which differ in ability to fix toxin can be separated chromatographically. Complexes of ganglioside with phrenosine and sphingomyelin have diminished toxin-fixing capacity. Tetanus toxin and ganglioside have a high binding capacity for calcium, but calcium does not affect the fixation of toxin by ganglioside. Ganglioside fixes strychnine, brucine and thebaine, drugs which have the same neurophysiological activity as tetanus toxin. Ganglioside does not fix $\gamma$-aminobutyric acid, $\beta$-hydroxy- $\gamma$-aminobutyric acid, histamine, adrenaline, noradrenaline or dopamine, but it does fix serotonin and a number of related compounds. It has been confirmed that albumin is fixed to a small extent by ganglioside at low salt concentration, but (unlike tetanus toxin) this fixation is practically abolished at physiological salt concentration.
\end{abstract}

\section{INTRODUCTION}

Previous work showed that ganglioside from nervous tissue acts as a specific receptor for tetanus toxin (van Heyningen, $1959 a, b, c$; van Heyningen \& Miller, 1961) The sialic acid residue(s) and its free carboxyl group were shown to be essential for the fixation of the toxin, and a sample of hexosamine-free ganglioside from horse red blood cells was found to be incapable of fixing toxin (van Heyningen $\&$ Miller, 1961). This paper reports further studies on the structural requirements in ganglioside for toxin-fixation, on other aspects of the reaction, and on the fixation of a number of other substances.

\section{METHODS}

Materials. The tetanus toxin preparation, TD 464 D (van Heyningen, 1959 $b$ ), was supplied by Dr C. G. Pope and Dr R. O. Thomson of the Wellcome Research Laboratories. It contains $40 \%$ of protein, of which $75 \%$ is toxin. Beef brain ganglioside was prepared by the method of van Heyningen \& Miller (1961). A number of isolated beef brain gangliosides were supplied by Professor Richard Kuhn of Heidelberg. Normal human brain ganglioside was supplied by Professor Erwin Chargaff of New York. Glycolipid preparations from human, horse, beef, sheep, cat and guinea pig red blood cells; horse, beef and human spleen; human and 
horse kidney; and horse lung, were supplied by Professor T. Yamakawa of Tokyo. Samples of hexosamine-free and hexosamine-containing ganglioside from brain were supplied by Professor Ernst Klenk of Cologne; samples of Tay-Sachs ganglioside by Professors Yamakawa, Klenk and Chargaff and by Dr S. Gatt of Jerusalem; colominic acid by Dr G. T. Mills of New York; endotoxin preparations by Professor Otto Westphal of Freiburg; oligosaccharide preparations from milk by Professor Richard Kuhn; phrenosine and sphingomyelin by Professor Herbert E. Carter of Urbana; histone (10\%, w/w, arginine) by Dr L. S. Wolfe of Montreal; $\gamma$-aminobutyric acid and $\beta$-hydroxy- $\gamma$-aminobutyric acid by Professor S. P. Halbert of New York; serotonin creatinine sulphate by Dr D. W. Woolley of New York; dopamine hydrochloride by $\mathrm{Dr} \mathrm{H}$. Blaschko of Oxford; adrenaline and noradrenaline were obtained from Burroughs Wellcome, London; tryptamine hydrochloride, histamine dihydrochloride, strychnine sulphate, brucine sulphate, ergometrine acid maleate and reserpine (of which a stock solution was prepared by dissolving $100 \mathrm{mg}$. in $5 \mathrm{ml} . \mathbf{2 0} \%$, w/v, ascorbic acid in water) from British Drug Houses Ltd, London; thebaine from May and Baker, London; lysergic acid diethylamide (LSD-25) from Sandoz Ltd, London; purified bovine plasma albumin Fraction V from Armour Laboratories, London.

Chromatography. Column chromatography was done on Mallinckrodts Analytical Reagent Acid 100 mesh silicic acid (Savory and Moore, London) ground to 300 mesh, and treated according to Hirsch \& Ahrens (1958). Silicic acid (10 g.) was suspended in $35 \mathrm{ml}$. chloroform, poured into tubes, $1.5 \mathrm{~cm}$. diameter, $25 \mathrm{~cm}$. long, and washed with a further $50 \mathrm{ml}$. chloroform. Ascending paper chromatography was done as described by van Heyningen \& Miller (1961).

Analyses. Sialic acid was determined by the resorcinol method of Svennerholm (1957) with methoxy- $N$-acetylneuraminic acid (supplied by Professor Klenk) as standard. Hexosamine was determined by the Procedure A of Svennerholm (1956) with glucosamine hydrochloride as standard. The following substances were analysed by measuring their optical densities at the wavelengths indicated; histamine, $225 \mathrm{~m} \mu$; strychnine, $255 \mathrm{~m} \mu$; brucine, reserpine, $265 \mathrm{~m} \mu$; adrenaline, noradrenaline, dopamine, serotonin, tryptamine, $279 \mathrm{~m} \mu$; thebaine, morphine, $285 \mathrm{~m} \mu$; lysergic acid diethylamide, $290 \mathrm{~m} \mu$; ergometrine, $315 \mathrm{~m} \mu$. The absorption by ganglioside at these wavelengths was negligible. When serotonin was estimated in the presence of other substances absorbing in the ultraviolet region the 1-nitroso-2naphthol method of Udenfriend, Weissbach \& Clark (1955) was used. $\gamma$-Aminobutyric acid and $\beta$-hydroxy- $\gamma$-aminobutyric acid were estimated by the ninhydrin reaction.

Ultracentrifugal studies. The Spinco Model E Analytical Ultracentrifuge with RTIC unit and with a phase plate at $60^{\circ}$ angle in the schlieren optical system was used. Reactants were dissolved in $0 \cdot 1 \mathrm{M}$-phosphate buffer (pH $7 \cdot 0)$ and placed in one of the sectors of a double sector cell with buffer in the other. Runs were carried out for $64 \mathrm{~min}$. at $42,040 \mathrm{rev}$./min. at $18^{\circ}-21^{\circ}$. Toxin-fixing capacity of ganglioside preparations was measured by the method of van Heyningen \& Miller (1961), but expressed as mg. toxin fixed/mg. ganglioside, rather than Receptor Units (RU), since the relation of toxin fixed per unit ganglioside appears on further investigation to be reasonably linear. A value of $300 \mathrm{RU} / \mathrm{mg}$. corresponds to about $1 \mathrm{mg}$. toxin fixed/mg. ganglioside. 


\section{Fixation of tetanus toxin and other substances by ganglioside}

\section{RESULTS}

\section{Toxin-fixation by various gangliosides and substances allied to gangliosides}

Yamakarva's glycolipids. The samples of glycolipids from red blood cells, spleen, kidney and lung supplied by Professor Yamakawa all contain lignoceric acid, sphingosine and hexose residues, and variable amounts of hexosamine and sialic acid ( $N$-glycollylneuraminic acid; cf. $N$-acetylneuraminic acid in brain ganglioside, Yamakawa, Irie \& Iwanaga, 1960). Nineteen samples of this material at a final concentration of $1 \mathrm{mg} . / \mathrm{ml}$. were tested in the analytical ultracentrifuge by the method of van Heyningen \& Miller (1961). Not one had any toxin-fixing capacity.

Endotoxins. The lipopolysaccharide endotoxins supplied by Professor Westphal were tested for toxin-fixing capacity because they resemble gangliosides in so far as they contain lipid and polysaccharide, are water soluble, and have a high sedimentation constant. Six endotoxin preparations were tested at a final concentration of $5 \mathrm{mg} . / \mathrm{ml}$. in the analytical ultracentrifuge and only one of these (Escherichia coli alk. 1447) fixed toxin. This sample, however, had been treated with alkali and is known to have the capacity to fix proteins indiscriminately (Lüderitz, Westphal, Eichenbeger \& Neter, 1958). The mixture of tetanus toxin and this substance did not give rise to a complex of fast-moving peaks in the ultracentrifuge, as is the case with brain ganglioside, but to a single peak which migrated more slowly than either the toxin or the lipopolysaccharide alone.

Colominic acid. Colominic acid is a polymer of $\mathrm{N}$-acetylneuraminic acid, with a high sedimentation constant (Barry, 1958). At a final concentration of $5 \mathrm{mg} . / \mathrm{ml}$. it did not fix tetanus toxin.

Milk oligosaccharides. Professor Kuhn provided 11 oligosaccharides from human and cow milk; 9 of these were tetrasaccharides containing residues of glucose, galactose, $N$-acetylgalactosamine and $N$-acetylneuraminic acid; one was a tetrasaccharide containing 2 galactose, 1 glucose and $1 \mathrm{~N}$-acetylgalactosamine residues; one was a trisaccharide containing galactose, glucose and $\mathrm{N}$-acetylgalactosamine. These oligosaccharides thus have a similar constitution to the oligosaccharide moiety of ganglioside, and in at least one of them the sequence of the residues is thought to be the same as in ganglioside (Kuhn, 1960). They were therefore tested for their ability to fix tetanus toxin. Since they had low sedimentation constants they could not be tested in the ultracentrifuge, but since they were diffusible through dialysing membranes, fixation was studied by equilibrium dialysis. Volumes $(2 \mathrm{ml}$.) of $0 \cdot 1 \mathrm{M}$-phosphate buffer ( $\mathrm{pH} 7$ ) containing $1 \cdot 4 \mathrm{mg}$. oligosaccharide $+2 \mathrm{mg}$. tetanus toxin $/ \mathrm{ml}$., or $1.4 \mathrm{mg}$. oligosaccharide alone $/ \mathrm{ml}$, , were dialysed against $2 \mathrm{ml}$. buffer with continuous agitation of the fluid on either side of the dialysing membrane for $48 \mathrm{hr}$. at $4^{\circ}$. The sialic acid content was then determined in the dialysis residue and diffusate in all cases except that of the tetrasaccharide which did not contain sialic acid; in this case hexosamine was determined. In all cases the sialic acid (or hexosamine) contents of the residue and diffusate were the same, indicating that the non-diffusible tetanus toxin had not fixed any of the oligosaccharides.

Hexosamine-free ganglioside. Klenk \& Gielen (1960) concluded from structural studies that brain ganglioside was a mixture of two gangliosides both containing sialic acid but only one containing hexosamine. They subsequently justified this conclusion by isolating two gangliosides, one with and one without hexosamine 
(Klenk \& Gielen, 1961). These were tested for toxin-fixing capacity. The hexosaminecontaining ganglioside fixed tetanus toxin in the usual way (3.8 mg. toxin/mg.) but the hexosamine-free brain ganglioside appeared to be incapable of fixing toxin.

Kuhn's gangliosides. Kuhn, Wiegandt \& Egge (1961) separated from normal human and beef brains 4 distinct crystalline gangliosides (G I to G IV) with decreasing mobilities on paper and silicic acid thin layer chromatography. These gangliosides all contained one residue each of stearic acid, sphingosine, glucose and $\mathrm{N}$-acetylgalactosamine, 2 residues each of galactose, but increasing proportions of $N$-acetylneuraminic acid as shown in Table 1 . Table 1 also shows that the toxinfixing capacities of these gangliosides varied considerably, and independently of sialic acid content. The value of about $19 \mathrm{mg}$. toxin fixed/mg. gangliosides G III and G IV is far higher than those hitherto encountered.

Table 1. Tetanus-toxin fixation by Kuhn's normal brain gangliosides

$\begin{array}{lcc}\text { Sample } & \begin{array}{c}\text { Residues } \\ \text { sialic acid/ } \\ \text { molecule }\end{array} & \begin{array}{c}\text { mg. toxin } \\ \text { fixed/mg. }\end{array} \\ \text { G I } & 1 & \mathbf{2 \cdot 5 9} \\ \text { G II } & 2 & \mathbf{3 \cdot 6 4} \\ \text { G III } & 2 & \mathbf{1 9 \cdot 3 0} \\ \text { G IV } & 3 & 19 \cdot 00\end{array}$

Table 2. Tetanus toxin-fixing capacity of samples of Tay-Sachs ganglioside, compared with two samples of normal human brain ganglioside

$\begin{array}{lcc}\text { Source of ganglioside } & \begin{array}{c}\mu \text { mole sialic } \\ \text { acid/mg. }\end{array} & \begin{array}{c}\text { mg. } \text { toxin fixed/ } \\ \text { mg. ganglioside }\end{array} \\ \text { Yamakawa } & 0 \cdot 75 & 0 \\ \text { Gatt 6 } & 0 \cdot 73 & 0 \\ \text { Gatt 2 } & 0 \cdot 59 & 0 \cdot 27 \\ \text { Gatt 4 } & 0 \cdot 31 & 0 \cdot 33 \\ \text { Gatt 3 } & 0 \cdot 39 & 0 \cdot 53 \\ \text { Chargaff } & 0 \cdot 52 & 0 \cdot 64 \\ \text { Gatt 5 } & 0 \cdot 55 & 0 \cdot 69 \\ \text { Chargaff } & 0 \cdot 75 & 0 \cdot 90 \\ \text { Gatt 1 } & 0 \cdot 53 & 1 \cdot 33 \\ \text { Klenk } & 0 \cdot 42 & 1 \cdot 35 \\ \text { Klenk (Normal)* } & 0 \cdot 66 & 1 \cdot 80 \\ \text { Chargaff (Normal)* } & 0 \cdot 89 & \mathbf{3 . 9 7}\end{array}$

* See Table 1, Bernheimer \& van Heyningen (1961).

Tay-Sachs gangliosides. Table 2 shows the tetanus toxin-fixing capacities of a number of samples of ganglioside isolated from the brains of infants dying of Tay-Sachs disease. Toxin-fixing capacity was always less than that of normal human brain ganglioside (about $4 \mathrm{mg}$. toxin fixed/mg. ganglioside) and varied from nil to values quite near those of normal ganglioside. Samples Gatt 6 (0 mg. toxin/mg. ganglioside) and Gatt $2(0.27 \mathrm{mg}$. toxin $/ \mathrm{mg}$. ganglioside) were obtained after samples Gatt 5 (0.69 mg. toxin/mg. ganglioside) and Gatt 1 (1.33 mg. toxin/mg. ganglioside), respectively, had been further purified by chromatography on silicic acid columns by Dr S. Gatt. Samples of normal brain ganglioside purified by Dr S. Gatt by the same procedure had the usual toxin-fixing capacity (about 
Fixation of tetanus toxin and other substances by ganglioside 379

$4 \mathrm{mg}$. toxin/mg. ganglioside). The purified samples Gatt 6 contained the usual proportions of sialic acid (0.73 $\mu \mathrm{mole} / \mathrm{mg}$.) and hexosamine (0.71 $\mu \mathrm{mole} / \mathrm{mg}$.). Thus it seems that in Tay-Sachs brains there is a ganglioside, not present in normal brains, containing the usual proportions of sialic acid and hexosamine, but incapable of fixing tetanus toxin. The other samples of Tay-Sachs ganglioside listed in Table 1 were evidently contaminated with different proportions of normal toxin-fixing ganglioside (see Gatt, 1962).
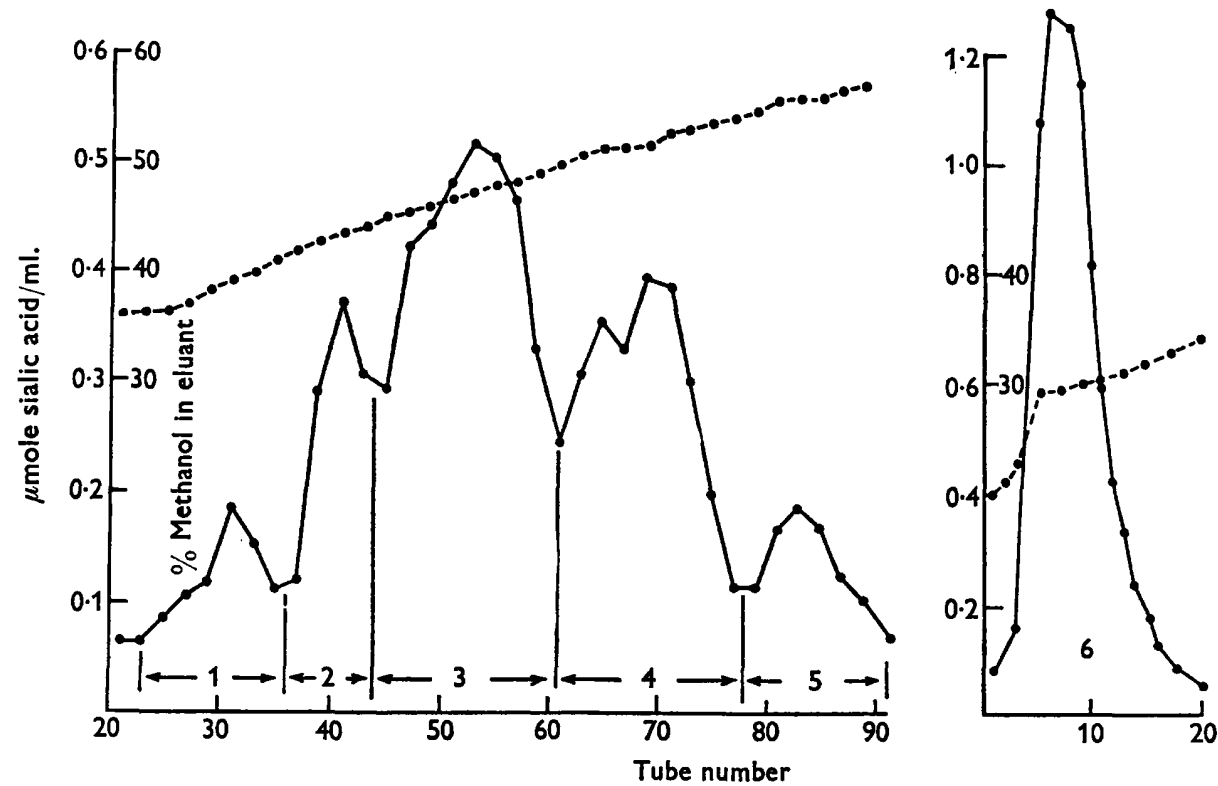

Fig. 1. Peaks 1-5, ganglioside fractions separated from chloroform + methanol extract of brain on silicic acid column. Peak 6, extract partitioned with water and material in water phase chromatographed.

Table 3. Data on the preparations emerging in the peaks shown in Fig. 1

\begin{tabular}{|c|c|c|c|c|c|}
\hline Peak & $\begin{array}{c}\text { Weight } \\
\text { (mg.) }\end{array}$ & $\begin{array}{c}\mu \mathrm{mole} \\
\text { sialic acid } / \mathrm{mg} .\end{array}$ & $\begin{array}{l}\mu \text { mole hexos- } \\
\text { amine/mg. }\end{array}$ & $\begin{array}{c}\text { Ratio } \\
\text { sialic acid/ } \\
\text { hexosamine }\end{array}$ & $\begin{array}{l}\text { mg. toxin } \\
\text { fixed/mg. }\end{array}$ \\
\hline 1 & 33 & $0 \cdot 19$ & $0 \cdot 15$ & $1 \cdot 3$ & 0.84 \\
\hline 2 & 27 & 0.36 & $0 \cdot 18$ & $2 \cdot 0$ & 1.00 \\
\hline 3 & 48 & $0 \cdot 48$ & $0 \cdot 21$ & $2 \cdot 3$ & $1 \cdot 20$ \\
\hline 4 & 36 & 0.65 & 0.23 & $2 \cdot 8$ & 6.60 \\
\hline 5 & 17 & 0.47 & $0 \cdot 16$ & $2 \cdot 9$ & 5.50 \\
\hline 6 & 160 & $0 \cdot 60$ & 0.21 & $2 \cdot 9$ & 3.33 \\
\hline
\end{tabular}

Ganglioside in chloroform-methanol extracts of brain. Beef brain was dehydrated by treatment with acetone and each g. dried residue extracted with continuous stirring for $7 \mathrm{hr}$. with $20 \mathrm{ml}$. of $67 \%(\mathrm{v} / \mathrm{v})$ methanol in chloroform. The solvent of the extract was evaporated off and the residue dissolved in a quarter volume of $20 \%$ methanol in chloroform. An excess of this solution (containing $10 \mathrm{~g}$. extract) was loaded on a column of $10 \mathrm{~g}$. silicic acid suspended in chloroform and the column washed with $20 \%$ methanol in chloroform until no material containing sialic acid appeared in the eluate. The column was then eluted with a chloroform + methanol 
gradient ranging from 30 to $60 \%$ methanol. The eluate was collected in $10 \mathrm{ml}$. volumes and the sialic acid content determined in alternate tubes. Over the range 36-57\% methanol five distinct sialic acid peaks emerged (Fig. 1). The contents of the tubes were pooled in five fractions as indicated in Fig. 1 and the dry weight, sialic acid and hexosamine contents, and toxin-fixing capacities of the fractions was determined (Table 3). The material in these peaks was water-soluble. Figure 2 shows paper chromatograms of the five fractions, interspersed with samples of a partially purified preparation of ganglioside. Fraction 1 appears to consist almost entirely of 'fast' ganglioside, fractions 2-5 of mixtures of 'fast' and 'slow' ganglioside (van Heyningen \& Miller, 1961). None of the fractions appear to be grossly contaminated with other lipids.

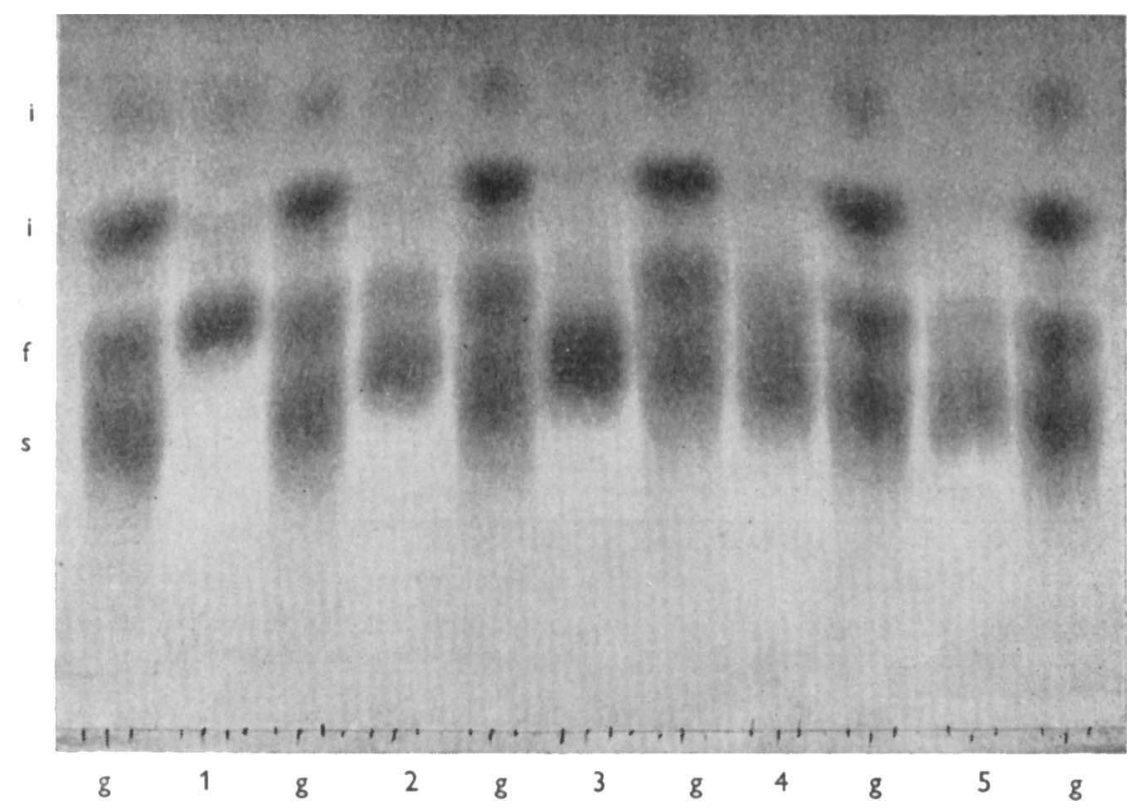

Fig. 2. Ascending paper chromatogram of the material emerging in the five peaks shown in Fig. 1, interspersed with samples of partially purified ganglioside (g). $i$, impurities; f, 'fast' ganglioside; s, 'slow' ganglioside.

A sample of the original chloroform + methanol extract was subjected to partitiondialysis and, after drying down, the material appearing in the upper aqueous phase was loaded on to a silicic acid column. The column was exhaustively percolated with $10 \%$ methanol in chloroform, and then eluted with a chloroform + methanol gradient ranging from 20 to $40 \%$ methanol. The eluate was collected in $10 \mathrm{ml}$. fractions and alternate fractions analysed for sialic acid (peak 6, Fig. 1). The single peak from this preparation emerged at a lower range of methanol concentrations $(20-34 \%)$ than the five peaks from the unpartitioned chloroform methanol extract $(36-57 \%)$. The data on the material in this single peak are shown in Table 3. These may be compared with the values of $0.88 \mu$ mole sialic acid/mg., $0.28 \mu$ mole hexosamine/mg., sialic acid-hexosamine ratio $3 \cdot 1,4 \mathrm{mg}$. toxin fixed $/ \mathrm{mg}$. for a purified preparation of 'slow' ganglioside (van Heyningen \& Miller, 1961). 


\section{Fixation of tetanus toxin and other substances by ganglioside 381}

Complexes of ganglioside with cerebroside and sphingomyelin. Although ganglioside is water-soluble, it is not extractable from mammalian brain with water. Van Heyningen $(1959 c)$ showed that ganglioside is complexed with cerebrosides and sphingomyelin in the crude 'protagon' fraction of brain. These complexes are water-insoluble or water-soluble according to the relative proportions of insoluble cerebrosides or sphingomyelin and soluble ganglioside. A study was made in the analytical ultracentrifuge of the water-soluble complexes and their toxin-fixing capacity.

To make the complexes, $10 \mathrm{mg}$. phrenosine or $10 \mathrm{mg}$. sphingomyelin $+20 \mathrm{mg}$. ganglioside were dissolved in $10 \mathrm{ml} .33 \%$ methanol in chloroform to give clear solutions. The solvent was evaporated off and the residues dissolved in $4 \mathrm{ml}$. water to give slightly opalescent solutions. In the ultracentrifuge the ganglioside+ phrenosine and ganglioside + sphingomyelin preparations sedimented as single peaks with the areas and sedimentation constants shown in Table 4. Besides the solubilization of phrenosine and sphingomyelin in water, complex formation with ganglioside is indicated by the single peaks of appropriately increased area and sedimentation rate. Similar solutions of the complexes were incubated overnight at $37^{\circ}$ with $50 \mu \mathrm{g}$. (850,000 LD 50) tetanus toxin protein $/ \mathrm{ml}$. Table 4 shows that the behaviour of the complexes in the ultracentrifuge was apparently unaffected.

Table 4. Areas and sedimentation constants of ganglioside, ganglioside + phrenosine and ganglioside + sphingomyelin peaks in the analytical ultracentrifuge before and after treatment with tetanus toxin

Final concentrations : ganglioside, $5 \mathrm{mg} . / \mathrm{ml}$.; phrenosine, $2.5 \mathrm{mg} . / \mathrm{ml}$; ; sphingomyelin, $2.5 \mathrm{mg} . / \mathrm{ml}$. See text for details of treatment with toxin.

$\begin{array}{lcc} & \begin{array}{c}\text { Area of peak* } \\ \left(\mathbf{m m} .^{2}\right)\end{array} & \begin{array}{c}\text { Sedimentation } \\ \text { constant } \dagger\end{array} \\ \text { Ganglioside } & \mathbf{1 8 \cdot 8} & \mathbf{1 3 \cdot 5} \\ \text { Ganglioside + phrenosine } & \mathbf{2 7 \cdot 4} & \mathbf{2 0 \cdot 5} \\ \text { Ganglioside + phrenosine } & \mathbf{2 7 \cdot 6} & \mathbf{2 0 \cdot 0} \\ \text { (toxin treated) } & & \\ \text { Ganglioside + sphingomyelin } & \mathbf{3 0 \cdot 0} & \mathbf{1 9 \cdot 5} \\ \text { Ganglioside + sphingomyelin } & \mathbf{2 9 \cdot 8} & \mathbf{2 0 \cdot 5} \\ \text { (toxin treated) } & & \end{array}$

* Area on photographic plate after $16 \mathrm{~min}$. sedimentation, uncorrected for sectorial effect.

$\dagger$ At $18^{\circ}$ in $0 \cdot 1$ M-phosphate buffer pH 7 .

Toxin fixation by these complexes was determined at a final concentration of $0.5 \mathrm{mg}$. ganglioside/ml. and $0.25 \mathrm{mg}$. phrenosine or sphingomyelin $/ \mathrm{ml}$. The following values were obtained: ganglioside alone, $3.56 \mathrm{mg}$. toxin/ $/ \mathrm{mg}$. ganglioside; ganglioside + phrenosine, $1 \cdot 10 \mathrm{mg}$. toxin/mg. ganglioside; ganglioside + sphingomyelin, $0 \cdot 93 \mathrm{mg}$. toxin/mg. ganglioside. Evidently complexing with phrenosine or sphingomyelin decreased the toxin-fixing capacity of ganglioside to about one-third.

Effect of histone on toxin fixation by ganglioside. McIlwain (1961) showed that the metabolic response of brain slices to electrical stimulation was decreased under certain conditions, including the addition of histone to the slices, and that the addition of ganglioside restored the response. He also showed that the addition of histone to brain emulsions decreased the amount of ganglioside that could be 
extracted with chloroform + methanol. The interaction of histone and ganglioside, and the effect of histone on the fixation of toxin by ganglioside, was therefore studied in the ultracentrifuge. A sample of histone containing $10 \%$ arginine was used. The peak of histone alone at a concentration of $5 \mathrm{mg} . / \mathrm{ml}$. barely moved away from the meniscus after $64 \mathrm{~min}$. at $42,040 \mathrm{rev} . / \mathrm{min}$. When ganglioside at $2.5 \mathrm{mg} . / \mathrm{ml}$. was added the histone peak did not move any further, but was slightly decreased in height, and its leading edge merged with the trailing edge of the ganglioside peak, the sedimentation rate of which appeared to be diminished. For these reasons it was not possible to make a quantitative measure of histone fixation by ganglioside, but a very rough estimate based on the decrease in the height of the histone peak suggests that about $1.5 \mathrm{mg}$. histone may be fixed by $2.5 \mathrm{mg}$. ganglioside under these circumstances (compare $4 \mathrm{mg}$. tetanus toxin/mg. ganglioside). This experiment suggested that histone decreased the sedimentation rate of ganglioside; this was confirmed by the following sedimentation constants $\left(20^{\circ}, 0 \cdot 1 \mathrm{M}\right.$-phosphate buffer, pH 7) : ganglioside (14 mg./ml.), 12.9 ; ganglioside (14 mg. $/ \mathrm{ml}$.) + histone $(2 \mathrm{mg} . / \mathrm{ml}$.), 9.0. The ganglioside + histone peak was sharper than that of ganglioside alone. The effect of histone was to increase the toxin-fixing capacity of ganglioside, rather than to diminish it. Under the conditions of the test, $0.5 \mathrm{mg}$. ganglioside fixed $2 \mathrm{mg}$. toxin, but when $1 \mathrm{mg}$. histone was added all the available toxin, $3.75 \mathrm{mg}$, was fixed. A control experiment showed that histone alone $(10 \mathrm{mg} . / \mathrm{ml}$.) had no effect on the toxin peak.

Binding of calcium ions by tetanus toxin and ganglioside. For reasons irrelevant to the present paper, the binding of calcium ions by toxin and ganglioside was determined in collaboration with Dr R. Woodman. Toxin and ganglioside were decalcified by dialysis for 2 days against several changes of 0.025 M-ethylenediamine-tetra-acetic acid followed by 2 days against several changes of water. The dialysed solutions were freeze-dried. To determine calcium binding, $4 \mathrm{ml}$. volumes containing $0.1 \mathrm{mg}$. toxin or $0.1 \mathrm{mg}$. ganglioside/ml. $0.5 \mathrm{~mm}-\mathrm{CaCl}_{2}$ in $5 \mathrm{~mm}$-imidazole buffer ( $\mathrm{pH}$ ) ) were dialysed against $4 \mathrm{ml}$. buffer with continuous agitation for $24 \mathrm{hr}$. at $3^{\circ}$. The calcium contents of the dialysis diffusate and the dialysis residue were then determined and it was calculated that under these circumstances tetanus toxin bound $1.18 \mathrm{~m}$-mole $\mathrm{Ca}^{2+} / \mathrm{g}$. and ganglioside $1.87 \mathrm{~m}$-mole $\mathrm{Ca}^{2+} / \mathrm{g}$. This finding that both ganglioside and toxin appeared to have high calcium-binding capacities suggested the possibility that the calcium ion might form a link between the toxin and the carboxyl group of ganglioside during the fixation of toxin by ganglioside. The fixation of decalcified toxin $(5 \mathrm{mg} . / \mathrm{ml}$.; $0.02 \mathrm{~m}$-mole $\mathrm{Ca} / \mathrm{g}$.) by decalcified ganglioside $(2.5 \mathrm{mg} . / \mathrm{ml}$; $0.035 \mathrm{~m}$-mole $\mathrm{Ca} / \mathrm{g}$.) in $0.01 \mathrm{M}$-imidazole buffer was measured in the presence and absence of calcium chloride added to a final concentration of $0.05 \mathrm{M}$. The toxin fixed in the presence and absence of added calcium was, respectively, 3.61 and $3.59 \mathrm{mg}$. toxin/mg. ganglioside.

\section{Fixation of albumin by ganglioside}

Doery \& North (1961) claimed that plasma albumin is fixed by ganglioside, and by implication equated the fixation of tetanus toxin and albumin. Their evidence for the fixation of albumin was based on an increase in the sedimentation constant of albumin in the presence of a high concentration $(5 \mathrm{mg} . / \mathrm{ml}$.) of ganglioside. 
Fixation of tetanus toxin and other substances by ganglioside $\mathbf{3 8 3}$

During the early stages of the present work (van Heyningen, $1959 b$ ) it was shown that the crude tetanus toxin receptor also fixed certain other proteins, namely lysozyme, trypsin and plasma albumin, at low salt concentration. However, it was also shown that the fixation of these proteins was different from that of tetanus toxin, since it was strongly diminished, if not abolished, at physiological salt concentration, whereas the fixation of tetanus toxin was unaffected by salt. The fixation of plasma albumin by ganglioside was investigated in the ultracentrifuge. In 0.1 M-phosphate buffer ( $\mathrm{pH} \mathrm{7}$ ) $0.15 \mathrm{mg}$. albumin was fixed/mg. ganglioside (compare $4 \mathrm{mg}$. toxin/mg.); in salt-free water the fixation of albumin was doubled and the fixation of toxin unaffected.

\section{The fixation of strychnine and other convulsant drugs by ganglioside}

It has long been recognized that strychnine and tetanus toxin have the same pharmacological action (see Sherrington, 1947). In more recent years it has been demonstrated that, like tetanus toxin, strychnine suppresses synaptic inhibition. The convulsant drugs brucine (a dimethoxy derivative of strychnine) and thebaine (a dimethoxy derivative of morphine) have a similar action (see Eccles, 1957). Morphine is a narcotic drug with a convulsant action under certain circumstances (see Goodman \& Gilman, 1960). The possible fixation of these drugs by ganglioside was therefore investigated. For these studies the fixed and moving partition cells of the Spinco Model E Analytical Ultracentrifuge were used (see Schachman, 1959). Ganglioside and drug were mixed at a final concentration of $4 \mathrm{~mm}$ and centrifuged

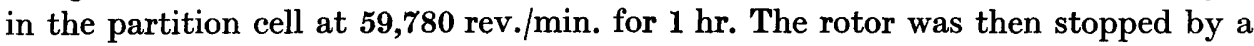
cautious application of the brake (see Schachman, 1959) and the contents of the upper and lower portions of the separation cells analysed for ganglioside and drug. In all cases all the ganglioside was found in the lower portion. The drugs alone did not migrate appreciably. From the data thus obtained the weight of drug fixed by ganglioside could be determined. These values are shown in Table 5. Other studies showed that the fixation of strychnine was more or less directly proportional to the concentrations both of strychnine and ganglioside.

Table 5. Fixation of convulsant drugs by ganglioside

$\begin{array}{lc} & \begin{array}{c}\text { Moles fixed/ } \\ \text { mole ganglioside* }\end{array} \\ \text { Tetanus toxin } & \mathbf{0 . 0 8} \\ \text { Strychnine } & \mathbf{0 . 2 8} \\ \text { Brucine } & \mathbf{0 . 2 4} \\ \text { Thebaine } & \mathbf{0 . 3 2} \\ \text { Morphine } & \mathbf{0 . 1 1}\end{array}$

* Assuming a molecular weight of 1384 for ganglioside.

When tetanus toxin was added to ganglioside at a final concentration of $5 \mathbf{m g}$. protein $/ \mathrm{ml}$., before strychnine was added, the fixation of strychnine was decreased by about half. This concentration of toxin ( $5 \mathrm{mg}$. protein $/ 5 \mathrm{mg}$. ganglioside) is not nearly enough to 'saturate' the ganglioside, but it was impracticable to use a higher concentration. On the other hand, in a system containing $5 \mathrm{mg}$. toxin protein $/ \mathrm{ml}$. 
and $0.5 \mathrm{mg}$. ganglioside $/ \mathrm{ml}$., the addition of $6 \mathrm{mg}$. strychnine $/ \mathrm{ml}$. increased the fixation of toxin from $1.52 \mathrm{mg}$. toxin $/ 0.5 \mathrm{mg}$. ganglioside to $2.46 \mathrm{mg}$. toxin $/ 0.5 \mathrm{mg}$. ganglioside.

\section{The fixation of serotonin and related drugs}

Tetanus toxin acts by suppressing synaptic inhibition, but the nature of the inhibitory transmitter (if any) is not known. A number of substances have at one time or another been suggested, with greater or less emphasis, as possible inhibitory transmitters, including $\gamma$-aminobutyric acid, $\beta$-hydroxy- $\gamma$-aminobutyric acid, histamine, adrenaline, noradrenaline, dopamine and serotonin (see Florey, 1961). The fixation of these substances (at $4 \mathrm{~mm}$ ) by ganglioside (at $4 \mathrm{~mm}$ ) was tested in the partition cells of the analytical ultra centrifuge in the same way as was strychnine. The drugs alone did not migrate appreciably. None of the drugs was fixed, except serotonin (see Table 6). Control experiments showed that creatinine sulphate (the serotonin was used as serotonin creatinine sulphate) was not fixed by ganglioside. The fixation of serotonin was proportional to the concentration of serotonin and of ganglioside. The hexosamine-free ganglioside isolated by Klenk

Table 6. Fixation of serotonin and related drugs by ganglioside

$\begin{array}{lc} & \begin{array}{c}\text { Moles fix } \\ \text { mole gangli }\end{array} \\ \text { Serotonin } & 0 \cdot 15 \\ \text { Tryptamine } & 0 \cdot 18 \\ \text { LSD-25 } & 0 \cdot 37 \\ \text { Ergometrine } & 0 \cdot 21 \\ \text { Reserpine } & 0 \\ \text { Chlorpromazine } & 0 \cdot 76\end{array}$

* Assuming a molecular weight of 1384 for ganglioside.

\& Gielen (1961) from normal human brain that did not fix tetanus toxin also did not fix serotonin. The hexosamine-containing Tay-Sachs ganglioside (Gatt 6) which did not fix tetanus toxin fixed only one-third as much serotonin as normal brain ganglioside $(0.048$ mole serotonin/mole Tay-Sachs ganglioside; compare Table 6). Tetanus toxin $(5 \mathrm{mg} . / \mathrm{ml}$.) did not affect the fixation of serotonin, and serotonin did not affect the fixation of toxin. Several drugs chemically or pharmacologically related to serotonin were also fixed by ganglioside, namely tryptamine, lysergic acid diethylamide (LSD-25) and ergometrine (Table 6); reserpine was not fixed. Harris, Saiffer \& Volk (1960) reported that chlorpromazine was fixed by ganglioside in equilibrium dialysis experiments, and Table 6 shows that this observation was confirmed in the ultracentrifuge. (Chlorpromazine is also avidly fixed by the rubber springs of the Yphantis moving partition cell of the ultracentrifuge, and the fixed partition cell had to be used in these experiments.) In the presence of 4 mM-LSD-25 or ergometrine the fixation of serotonin was somewhat decreased (from $0 \cdot 15$ to $0 \cdot 10$ and $0.08 \mathrm{~mole} /$ mole ganglioside, respectively).

When serotonin was incubated with 10 million LD50 doses of tetanus toxin $/ \mathrm{ml}$. for $6 \mathrm{hr}$. at $37^{\circ}$ there was no decrease in its capacity to yield a chromophore with 1-nitroso-2-naphthol (Udenfriend et al. 1955), or in its capacity to stimulate guineapig ileum. 


\section{Fixation of tetanus toxin and other substances by ganglioside}

\section{DISCUSSION}

Almost invariably the word 'ganglioside' should be read as 'a mixture of gangliosides' (see Rapport \& Norton, 1962). Klenk \& Gielen (1961) showed that there are at least two gangliosides containing one residue of sialic acid per molecule; in one the residues of the oligosaccharide moiety are in a chain, and include hexosamine; in the other the oligosaccharide moiety is branched and hexosamine is replaced by galactose. Kuhn et al. (1961) separated four different gangliosides, all containing hexosamine, but containing from 1 to 3 sialic acid residues. The hexosamine-free ganglioside of normal brain does not fix tetanus toxin, but there is a hexosaminecontaining ganglioside in Tay-Sachs brain which also does not fix toxin. The sialic acid residue of ganglioside is essential for tetanus toxin fixation, and to some extent toxin fixation is proportional to the sialic acid content of ganglioside (Bernheimer \& van Heyningen, 1961). But the experiments with the gangliosides isolated by Kuhn et al. (1961) showed that there could also be a considerable variation in toxin-fixing capacity which was independent of sialic acid content.

The separation of a number of crude gangliosides with widely different toxinfixing capacities from a chloroform + methanol extract of brain on a silicic acid column invites comparison with the four gangliosides of Kuhn et al. (1961). Gangliosides are usually obtained from chloroform + methanol extracts of brain after partition into an aqueous phase. The direct application of the crude chloroform + methanol extract to a silicic acid column may prove useful in eliminating this stage and in bringing about a more efficient separation of different gangliosides.

The fixation of tetanus toxin is ganglioside-specific and toxin-specific, and is avid, since some gangliosides fix up to twenty times their weight of tetanus toxin. North \& Doery (1961); Doery \& North (1961) claimed that other toxins, namely diphtheria and staphylococcal toxins, and proteins, e.g. plasma albumin, are fixed by ganglioside. The fixation of diphtheria and staphylococcal toxins was deduced from the fact that these toxins are inactivated on standing with ganglioside at $37^{\circ}$ in the absence of protective colloids. However, it has already been demonstrated that diphtheria toxin is not fixed by ganglioside, and it has been pointed out that the specific fixation of tetanus toxin is unrelated to the non-specific inactivation of a number of toxins (van Heyningen, 1961). The fixation of albumin by crude tetanus toxin receptor was demonstrated some years ago, when it was shown that this fixation was different from that of tetanus toxin since it was abolished by salt, which did not affect the fixation of tetanus toxin (van Heyningen, 1959b). In the present paper it has been shown that the fixation of albumin by gangliosides is of a smaller order of magnitude than that of tetanus toxin, and the inhibitory effect of salt has been confirmed. The fixation of strychnine, brucine and thebaine by ganglioside may be significant in view of the fact that these drugs have the same neurophysiological action as tetanus toxin. The fixation of serotonin by other substances besides ganglioside has been detected by other techniques by Dombro, Bradham, Campbell \& Woolley (1961).

I am glad to thank Dr Pope, Dr Thomson, Professor Yamakawa, Professor Westphal, Professor Klenk, Professor Kuhn, Professor Chargaff, Dr Gatt, Dr Mills, Dr Carter, Dr Halbert, Dr Wolfe, Dr Woolley and various members of the 
Pharmacology Department at Oxford for so kindly providing the various substances listed under Methods; Dr Gatt for useful discussions about his gangliosides; Dr J. A. Parsons for measuring the effect of serotonin on the guinea-pig ileum; Mr J. Otway, Miss Diana Messenger and Mrs Galatea Collins for able technical assistance. Very special thanks are due to the Wellcome Trustees for a grant for the Spinco Analytical Ultracentrifuge and to the Office of Naval Research of the United States Department of the Navy for continued financial support (Project no. 103-474).

\section{REFERENCES}

BARRY, G. T. (1958). Colominic acid, a polymer of $N$-acetylneuraminic acid. J. exp. Med. $107,507$.

Bernheimer, A. W. \& van Heyningen, W. E. (1961). The relation between the tetanus toxin-fixing and influenza virus-inhibiting properties of ganglioside. J. gen. Microbiol. 24, 121.

DoERY, H. M. \& NorTh, E. A. (1961). The interaction of staphylococcal toxin and ganglioside. 1. Inactivation of the lethal effect of staphylococcal toxin in mice. Aust. J. exp. Biol. med. Sci. 39, 333.

Dombro, R. S., Bradham, L. S., Campbell, N. K. \& Wooluey, D. W. (1961). Serotonin receptors. III. The role of salt formation. Biochim. biophys. Acta, 54, 516.

Eccles, J. C. (1957). The physiology of nerve cells. London: Oxford University Press. Florey, E. (editor) (1961). Nervous inhibition. Oxford: Pergamon Press.

GatT, S. (1962). Chloroform soluble complexes of gangliosides with lipids and salts. Bull. Res. Counc. Israel, 11 A, 90.

Goodman, L. S. \& Gilman, A. (1960). The pharmacological basis of therapeutics. New York: The Macmillan Company.

Harris, A. F., Saifer, A. \& Volk, B. W. (1960). Interaction of chlorpromazine with strandin. Proc. Soc. exp. Biol., N.Y. 104, 542.

Hrrsch, K. \& Ahrens, E. H. (1958). The separation of complex lipide mixtures by the use of silicic acid chromatography. J. biol. Chem. 233, 311.

Krenk, E. \& Gielen, W. (1960). Zur Kenntnis der Ganglioside des Gehirns. Hoppe-Seyl. Z. 319, 283.

KuENK, E. \& Gielen, W. (1961). Untersuchungen über die Konstitution der Ganglioside aus Menschengehirn und die Trennung des Gemisches in die Komponenten. HoppeSeyl. Z. 326, 144.

Kunn, R. (1960). Über die Ganglioside des Gehirns. Angerw. Chem. 72, 805.

Kuhn, R., Wiegandt, H. \& Egge, H. (1961). Zum Bauplan der Ganglioside. Angere. Chem. 73, 580.

Lüneritz, O., WestPhal, O., Eichenberger, E. \& Neter, E. (1958). Über die Komplexbildung von bakteriellen Lipopolysacchariden mit Proteinen und Lipoiden. Biochem. $Z$. 330, 21.

McIlwain, H. (1961). Characterization of naturally occurring materials which restore excitability to isolated cerebral tissues. Biochem. J. 78, 24.

North, E. A. \& DoEry, H. M. (1961). Inactivation of staphylococcal, tetanus and diphtheria toxins by ganglioside. Brit. J. exp. Path. 42, 23.

Rapport, M. M. \& Norton, W. T. (1962). Chemistry of the lipids. Annu. Rev. Biochem. $31,103$.

Schachman, H. K. (1959). Ultracentrifugation in biochemistry. New York: Academic Press Inc.

Sherrington, C. (1947). Integrative action of the nervous system. Cambridge: University Press.

Svennerholm, L. (1956). The determination of hexosamines with special reference to nervous tissue. Acta Soc. Med. upsalien. 61, 287.

Svennerholm, L. (1957). Quantitative estimation of sialic acids. II. A colorimetric resorcinol-hydrochloric acid method. Biochim. biophys. Acta, 24, 604. 
Fixation of tetanus toxin and other substances by ganglioside 387

Udenfriend, S., Weissbach, H. \& Clark, C. T. (1955). The estimation of 5-hydroxytryptamine (serotonin) in biological tissue. J. biol. Chem. 215, 337.

van Heyningen, W. E. (1959a). The fixation of tetanus toxin by nervous tissue. J. gen. Microbiol. 20, 291.

van Heyningen, W. E. (1959b). Chemical assay of the tetanus toxin receptor in nervous tissue. J. gen. Microbiol. 20, 301.

van Heyningen, W. E. $(\mathbf{1 9 5 9} c)$. Tentative identification of the tetanus toxin receptor in nervous tissue. $J$. gen. Microbiol. 20, 310.

van Heyningen, W. E. (1961). The relation between the fixation and inactivation of tetanus toxin by ganglioside. Brit. J. exp. Path. 42, 397.

van Heyningen, W. E. \& Mrleer, P. A. (1961). The fixation of tetanus toxin by ganglioside. J. gen. Microbiol. 24, 107.

Yamakawa, T., Irie, R. \& Iwanaga, M. (1960). The chemistry of lipid of posthemolytic residue or stroma of erythrocytes. J. Biochem. 48, 490 . 